\title{
An Empirical Examination on Trade Openness and Economic Growth Nexus in Africa
}

\author{
Cosmas S. Mbogela ${ }^{1}$ \\ 'Mzumbe University Business School, Box 6 Mzumbe, Tanzania \\ Email:cmbogela@gmail.com Tel:+255766599295
}

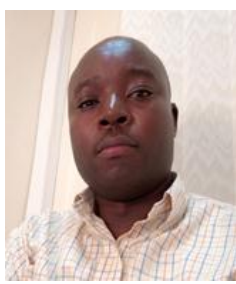

\begin{abstract}
African countries have experienced disparities in the growth of their economies. The literature provides different propositions on the causality of economic growth which has given rise to debates on the alternative course that countries need to pursue to enhance their respective growths economically. The paper has therefore examined the effects of trade openness on economic growth for the African countries. In order to analyse the link between trade openness and economic growth by using the growth model, the instrumental variables and two stage least squares (2SLS) for panel data models approach is employed. Later an examination of the direction and strength of causality is conducted by using such techniques as Johansen cointergration test and short run granger causality test. The paper uses data from the World Bank database. A sample size consists of 49 African countries with a sample period of 20 years. Empirical results reveal that of all the variables that were included in the growth model, gross capital formation revealed a great impact on economic growth for African economies, followed by openness and then FDI flows. A test of granger causality for individual countries so as to explain the economic disparities, reveals that majority of the African countries (in the sample) supports the export led growth hypothesis. Implications are that the export led hypothesis would be much more advantageous for the African countries if it would not only result into increased real incomes but also economic structural transformations.
\end{abstract}

Keywords: Trade openness, Economic growth, Export driven growth, Growth driven exports.

JEL Classification: E23, F10, F13.

Citation | Cosmas S. Mbogela (2019). An Empirical Examination on Trade Openness and Economic Growth Nexus in Africa. Asian Journal of Economics and Empirical Research, 6(1): 1-15. History:

Received: 18 September 2018

Revised: 26 October 2018

Accepted: 30 November 2018

Published: 24 December 2018

Licensed: This work is licensed under a Creative Commons Attribution 3.0 License $(\mathrm{cc})$ (

Publisher: Asian Online Journal Publishing Group
Funding: This study received no specific financial support

Competing Interests: The author declares that there are no conflicts of interests regarding the publication of this paper.

Transparency: The author confirms that the manuscript is an honest, accurate, and transparent account of the study was reported; that no vital features of the study have been omitted; and that any discrepancies from the study as planned have been explained.

Ethical: This study follows all ethical practices during writing.

\section{Contents}

1. Introduction

2. Channels through which Trade Openness affect Economic Growth .3

3. Growth Model Specification .........4

4. Further Examination on the Nature of Relationships and the Direction of Causality ....................................................

5. Conclusions

References 


\section{Introduction}

There has been much debates on the examination of the relationship between trade openness and economic growth in the theoretical and empirical literature (Dollar and Kraay, 2001; Ekanayake et al., 2003; Karras, 2003; Yanikkaya, 2003; Awokuse, 2008; Nannicini and Billmeier, 2011; Seetanah et al., 2012; Mercan et al., 2013; Menyah et al., 2014; Huchet-Bourdon et al., 2018). The reason is obvious that economies would want to establish the direction of causality so that they can focus their priorities on the part that causes the other. This is a crucial aspect, particularly to policy makers, who would need to decide if they should encourage trade openness to speed up their economic growth or the other way round; focus on enhancing economic growth that in turn would promote the degree at which they trade internationally (Harrison, 1996; Kónya, 2006).

The literature provides four possible propositions on the direction of causality on the two phenomena. The export led growth hypothesis (ELG), which is supported by most of the studies, provides that more exports results into higher economic growth rates (Onafowora and Owoye, 1998; Rodriguez and Rodrik, 2001; Din, 2004; Hassan and Islam, 2005). This hypothesis is complemented by the import led growth hypothesis (ILG) as suggested by Awokuse (2008). Coining the two hypotheses together results into country's aggregate trade hence trade openness. Most of the researchers supporting this hypothesis attribute positive effects of trade openness to economic growth. In a sense, this claims that openness enhances productivity in the economy through export promotion, importation of high quality technologies, as it is a prerequisite for the production of higher quality and competitive products and services. Besides, high quality technology has positive effects on labour productivity and capital efficiency (Kónya, 2006). In support of this proposition are studies such as Harrison (1996) and Rodriguez and Rodrik (2001) who examined the association between openness and economic growth and found a positive correlation between the two and in particular, the causality running from trade openness to economic growth.

Same conclusion is observed from studies like that of Din (2004) examining the ELG hypothesis in South Asian region countries, he found that there exists a long-run causality in Bangladesh and Pakistan with short run causality in some other Southern Asia countries. In addition, the study by Hassan and Islam (2005) finds a long-run uni-directional equilibrium relationship running from trade openness and economic growth. The study by Onafowora and Owoye (1998) who used Vector Error Correlation Model (VECM) in order to facilitate the dynamic analysis of the interactions among the variables, found that trade policies and exports have significant positive effects on the real output growth in Sub Sahara African countries. Consequently, this imply that outward orientation strategy might benefit Sub Saharan African countries in terms of stimulating their economic growth, though it also requires suitable domestic policies that discourage import substitution strategies.

Another hypothesis is the opposite of the above, the growth-driven export (GDE). This hypothesis predicts that trade flows are induced by the level of economic growth of a country. Higher trade volumes are expected to be associated with the economies with higher levels of GDP per capita. Studies of Awokuse (2008) suggest that the export -led growth may be misleading while the import-led growth as well as the causality running from income levels leading to increased export volumes hypothesis is having relatively stronger empirical evidence. However, there is a also an importance of realising the importance of ILG, because ignoring imports which is a source of inputs for the production of imports as well as technological knowledge is misleading.

Furthermore, there is a hypothesis that postulates the bi-directional causality, which means the causation runs from both sides. Empirical examples of studies supporting this hypothesis include (Ekanayake et al., 2003) who found a bi-directional causality between export growth and economic growth for both developed and developing countries. Examining the long run relationship between FDI, trade openness and economic growth (Klasra, 2011) observed a bi-directional causality between openness and economic growth in Pakistan. Some other studies include Dollar and Kraay (2001) in their study of 137 countries concluded that openness brings about enhanced and faster economic growth as well as reduction in poverty in poor countries. The last hypothesis postulates that there is no relationship between trade openness and economic growth. Examples are the study by Sarkar (2008) who examined the relationship between openness and economic growth and found that there is no positive long term relationship between the two variables particularly in the less developed countries.

However, some other researchers show that higher trade openness brings about different outcomes to different countries depending on the level of development. It has strong positive impacts on real income for developed countries with high incomes while having detrimental impacts to low income countries (Kim, 2011). This view is also supported by studies done by Krugman and Venables (1995); Caner and Hansen (2004). The contention is that, low-income economies benefit from trade liberalization but only if the opening up to international trade is carried out alongside with policy and institutional reforms toward investment, production efficiency, and financial development (Kim, 2011).

For this reason there is much in the literature that confirms the existence of the relationships that exists between economic growth and trade openness. The most appealing argument in the literature is that which claims a positive effect of openness on economic growth. David (2007) finds that raising trade openness by 10 per cent permanently increases real growth rate of GDP per capita by 0.5 per cent. It can be argued that developing countries to include African economies, tend to benefit more from this because of the fact that trade openness promotes transfer of technology from developed countries, which implies a positive spill over effect on world income distribution. Even the recent Chinese rapid economic growth is attributed to the country's increasing degree of opening up to international trade (Marelli and Signorelli, 2011). Moreover, the literature acknowledge that economies characterized with higher degrees of trade openness tend to grow faster than those with lower levels of openness (Din. et al., 2003) because trade openness enhances growth in a country's GDP per capita. Manole and Spatareanu (2010) reveals that countries (developing and developed) with less trade protectionism have higher growth of GDP per capita.

An empirical research by Edwards (1993) reveals that a higher level of a country's openness is associated with a higher level of economic growth, because among others a country open to international trade improve product quality and efficiency in production due to competition from foreign companies (Grossman and Helpman, 1991; Aizenman and Noy, 2003). Importing industries can also import technology and knowledge, where exporting sectors in turn can learn from this and improve their competitive position. 
Is it growth led exports or export led growth for African countries? Despite the fact that literature vindicates that openness to international trade (especially exports) has an influence to economic growth, we see mixed results (Huchet-Bourdon et al., 2018) there are studies that support both negative and positive impact, with scanty literature from Africa. This paper complements the literature by providing new insights on the relationship that exists between trade openness and economic growth for the African countries. The empirical results from this paper can be instrumental for African countries to analyse their trade policies and economic growth trends.

The remainder of the paper is organized as follows; next is the review of literature especially the channels through which outward orientation can affect economic growth. Section 3 provides a growth model specification. Section 4 provides an empirical examination of the nature and direction of the relationship between trade openness and economic growth. Section 5 concludes.

\section{Channels through which Trade Openness affect Economic Growth}

The literature presents three channels from economics that provide the nexus between trade openness and economic growth, to include government policy, domestic allocation and distribution and technology transfer (Rose, 2002). On the other hand, based on the neo-classical model of international trade (David, 2007) offers three channels including gains from exchange, specialization and economies of scale. Both consumers and producers will gain from trade openness due to increased imports of primary and intermediate inputs that will be at lower prices (gains from exchange). Moreover, by opening up borders, firms will direct resources away from the previously protected sectors to those that add more value to an economy and those that have a competitive advantage hence utilizing resources more diligently to increase outputs (gains from specialization). On the firm level, firms that will survive competition after liberalizing the economy, realises an increase in output and achieve lower average total costs. This enhances their efficient use of resources, which lead to higher output (gains from economies of scale).

Revisiting the channels by Rose (2002) the first channel is the government policy. Higher degree of openness compels countries to pursue good quality microeconomic policies so as to create favourable environments for inhibiting capital flights and being in line with the international and inter regional agreements. Since good policies create a stable microeconomic environment, these countries are expected to positively affect their economic growth for they not only eliminate price uncertainty in their economies but also moderate public deficit and debt levels. Eventually this enhances the capacity of the domestic firms to compete internationally (Rose, 2002).

Furthermore, open economies tend to have less price distortions because in economic theory, free trade facilitates price convergence of tradable goods across countries. The presence of trade restrictions generates price distortions that shift productions between economies leading to production processes that are not based on comparative advantage, hence consumers end up paying higher prices on goods and services (David, 2007). Since price distortions have adverse effects on factor accumulation and growth, open economies are then expected to enjoy positive effects on their economic growth by having less price distortions. Trade openness is positively related to domestic rate of physical investment. Investments enhance factor accumulations which is a major factor in economic development, specifically for developing economies moving from low economic growth equilibrium to a path of sustained industrialization (Rose, 2002).

The most common channel is through technological transmission. Knowledge spillages are a driving force for sustained and long run economic growth. Trade openness can affect growth and convergence through technology transmissions, because open economies are more exposed to a worldwide stock of productivity-enhancing knowledge (Falvey et al., 2002; Rose, 2002). The literature asserts that national policies that reduces the degree to which an economy is intergraded to external trade strengthens the undersupply of innovation in that respective economy (Grossman and Helpman, 1991). Innovation is central to any improvement in total factor productivity in any economy. Madsen finds that empirically that 93 per cent of the total factor productivity in the 1990's for the OECD countries has been solely due to knowledge spill over through imports. In fact even the total factor productivity convergence among these countries over the period 1870 to 2004 has been associated with knowledge spill over through international trade (Madsen, 2007).

Learning from East Asian growth miracle, trade openness enhances direct imports of high- tech goods as well as greater interactions with the sources of innovations through high international communications and mobility among economies. This has a positive advantage as it is easier for domestic producers in open economies to imitate foreign technologies in their productive process. This alone translates into economic growth as it boosts the capacities of the developing economies to compete with more advanced economies in the global market. It also lead to great transformations in the product composition of output and exports, developing countries will transform from relying heavily on agriculture to heavy industries as well as high-tech goods.

Open economies are better positioned to gain economically through efficient resource allocation. Efficient allocation of resources is associated with enhanced investments, productivity and growth (Kandiero and Chitiga, 2006). In the long run such economic environment is likely to attract FDIs which is vital channel to economic growth. And, since trade is positively related to FDI inflows, countries that desire to increase their FDI inflows levels should enhance their trade levels (Asiedu, 2006; Marelli and Signorelli, 2011). This is because trade and FDI are interrelated, as in most cases FDI is export oriented (Marelli and Signorelli, 2011). Thus, trade openness signals investors that a particular country is committed to stable and market oriented economic policies. Investors will see the possibility of importing intermediate goods for initiating new projects, be able to repatriate their profits as well as exporting the produced goods. With more FDI inflows, host economies obtain required financing resources for infrastructure development and rehabilitation of their economies.

Moreover, arguing in line with endogenous and neo classical growth models, FDI is positively associated with economic growth (Babatunde, 2011). With the FDI inflows, host countries benefit as they are being provoked to be competitive and to obtain new technologies, managerial expertise, marketing capabilities, which improve their human capital. Market competition enhances efficiency in the economy by reducing the degree of monopoly power that dominates most of the less open economies. FDI also enhances employment levels, managerial skills, diffuses technologies and fosters innovations in the economy (Asiedu, 2002; Kandiero and Chitiga, 2006; Adhikary, 2011). Likewise quoting Kandiero and Chitiga (2006) FDI inflows "stimulate capital accumulation through adding to 
domestic savings and raising the recipient economy's efficiency through improving resource allocation, deepening domestic financial markets and reducing local capital costs"

With all these, countries strengthen their supply-side capabilities for producing and selling goods and services, which lead to their economic growth. Moreover, with FDI host economies increase the volume and efficiency of their physical investment, which eventually promotes economic growth through aggregate expenditure and increased fixed capital stock. This is because fixed investments in part depend not only on the internal saving rate but also on the foreign investments through FDI (Adhikary, 2011; Marelli and Signorelli, 2011).

Trade openness enhances export volumes that can be used to pay for an increased value of imports, which in most cases leads to a positive net value of exports. This results into higher local savings and higher accumulation of foreign exchange reserves which can be invested for further earnings (Marelli and Signorelli, 2011). It is also good to note that private and public capital stock formation depends on fixed investment, which as noted earlier is largely supported by a high saving rate and foreign investment. The neo-classical growth model suggest that developing countries with lower initial level of capital stock tend to have higher marginal rate of returns (productivity) and growth rates if adequate capital stock is injected. This is because when additional capital is injected in the form of long term investment the marginal productivity of investment is increased in the short-run and this increased productivity have a long run positive effects on economic growth (Adhikary, 2011).

Moreover, in line with transaction theory (i.e. a low transaction cost environment generates financial incentives because of higher return on investment) trade openness tends to influence the flows of international capital in terms of risk-return relationship. Investors will feel interested in committing long-term investment in a country with lower tariff and non-tariff barriers on investment and allows repatriating capitals and profits (Adhikary, 2011). It is however, good to note that openness can also result from the level of economic growth of a country; among others Frankel and Romer (1999) have argued that economies experiencing rapid economic growth resulting from reasons other than openness are in a better chance to engage in the international trade.

\section{Growth Model Specification}

The paper establishes the causality relationships that exist between trade openness and economic growth in African countries, particularly Sub Saharan Africa. The variables of interest here are therefore mainly trade openness and GDP per capita. However, it is inevitable to examine the relationships in a growth model before testing for short run and long run relationships. Based on the Marelli and Signorelli (2011) study, the growth model to be used for this study is a function of trade openness, foreign direct investment, the workforce (population aged 15 to 64 as a percentage of total population), human capital development, initial conditions and gross capital formation. Thus the resultant general growth model is;

$$
\gamma_{i t=\beta^{0}}+\beta_{1} E_{i t}+\beta_{2} T O_{i t+} \beta_{3} x_{i}+\varepsilon_{i t}
$$

Where $\mathcal{Y}$ represents economic growth; $E$ are the control variables that affect economic growth in country $i$ at time $t$ (for this study are initial conditions, the workforce, foreign direct investment ratio, gross capital formation and human capital development). TO refers to a measure of level of trade openness; $x_{i}$ stands for country fixed effects; and $\varepsilon_{i t}$ is an error term.

However, economic growth modelling has two potential problems of inconsistency, the omitted variable bias and the endogeneity problem. The former arises when country specific effects are wrongly assumed uncorrelated with the other explanatory variables mainly because of the dynamic nature of the growth models. On the other hand, the latter problem may arise due to a failure to control for endogeneity, which might result into inconsistent estimation results (Tsangarides, 2001). In this case, it means that the ordinary linear regression cannot be used because the zero conditional mean assumption does not hold. In econometrics perspective, three main circumstances may result into the violation of this assumption, the endogeneity, omitted variable bias and the issue of errors in variables (i.e. measurement error in the explanatory variables).

To avoid all these potential problems, the model for this paper is estimated by using the instrumental variables and Two Stage Least Squares (2SLS) for panel data models. This is done through two estimators, the fixed effects estimator and random effect estimator. With the 2SLS, we first conduct a one stage estimation that include all the variables in the model, and then thereafter a further examination is done by instrumenting the trade openness variables in a 2 SLS approach. After obtaining the regression results, we examine the direction and strength of causality between the two variables as well as assessing the short run and long run relationships that exists between trade openness and economic growth. In the latter, unit root tests are conducted to check whether the panel data are stationary.

\subsection{Data and Variables}

This paper used the standard measure of trade openness is used (the sum of exports and imports as a proportion of GDP). GDP per capita growth (annual percentage) is the widely used proxy for economic growth in the literature (Dowrick and Golley, 2004; Bajwa and Siddiqi, 2011) and is therefore used to measure the economic growth of the sample of countries under consideration. The data are averaged in five years to reduce the noise in the data. Since the data are averaged in five years, the initial condition variable is measured by log of real GDP per capita in the first year of the five-year period under each observation (Cinyabuguma and Putterman, 2011). The secondary school enrolment ratio is used as a proxy for human capital development, which measures the quality of labour (Seetanah, 2009; Seetanah, 2011). The foreign direct investment flows and the gross capital formation variables are in percentage of GDP. The workforce variable is proxied by the ratio of population workforce (aged 15-64) as a percentage of the total population. This is considered as the most active population cadre in any economy.

All the data are from the World Bank database. Data are collected for 49 countries, which represent the sample size, and the sample period covering from 1989 to 2008 inclusive (that is 20 years). The selection of countries for the sample is based on the criteria that, only those countries with full data in almost all the sample period are included. Table 1 provides an account and description as well as the data sources for all the variables that will be used in this paper. 
All the data were then organised in a panel data form and are averaged in four five-year' time periods so as to reduce the noise in data. Besides, this helps to remove any business cycle effects in the dataset as well as to simplify the empirical analysis. Panel data analysis is used because it can exploit both the time series, cross sectional dimensions of data, and has proved to provide more efficient estimations of parameters by considering wider sources of variation. What's more, the use panel data avails a richer set of information to exploit the relationships between the dependent and independent variables.

The variable initial conditions are converted into natural logarithm before its usage in order to ensure that the data is normally distributed and properly skewed. The rest of the data are in percentages, hence, there was no need for logarithmic transformations.

\subsection{Growth Model Estimations Results}

In order to analyse the link between trade openness and economic growth by using the growth model, the instrumental variables and two stage least squares for panel data models approach is employed. The two stage least squares method with instrumental variables is employed because some of the covariates in the model (1.1) are endogenous (i.e. trade openness).This approach provides five different options of estimators with their variation being based on the way they treat the country individual effects. These options include the two GLS randomeffects (G2SLS and EC2SLS) model, the between-effects (BE2SLS) model, the fixed effects estimator (FE2SLS) and the first differenced estimator (FD2SLS) which take away individual effects by fitting the model in first differences. This paper opts for the random effect and fixed effect estimators, but we conduct these estimators in two stages.

Table-1. Variable description and sources of data

\begin{tabular}{|c|c|c|c|}
\hline Variable & Description of a variable & Source & \\
\hline $\begin{array}{l}\text { GDP per capita growth } \\
\text { (annual \%) }\end{array}$ & $\begin{array}{l}\text { This is a dependent variable. Annual percentage } \\
\text { growth rate of GDP per capita based on constant } 2005 \\
\text { U.S. dollars. GDP per capita is gross domestic product } \\
\text { divided by midyear population. }\end{array}$ & $\begin{array}{l}\text { World } \\
\text { database. }\end{array}$ & Bank \\
\hline Trade openness & $\begin{array}{l}\text { Measures aggregate trade (sum of exports and imports } \\
\text { of goods and services) as a ratio of GDP. }\end{array}$ & $\begin{array}{l}\text { World } \\
\text { database. }\end{array}$ & Bank \\
\hline Initial conditions & $\begin{array}{l}\text { A measure of GDP per capita in the first year of each } \\
\text { "five year period average" as used in this study. }\end{array}$ & $\begin{array}{l}\text { World } \\
\text { database. }\end{array}$ & Bank \\
\hline $\begin{array}{l}\text { Gross capital formation } \\
(\% G D P)\end{array}$ & $\begin{array}{l}\text { The variable consists of outlays on additions to the } \\
\text { fixed assets of the economy plus net changes in the } \\
\text { level of inventories. Fixed assets include land } \\
\text { improvements; plant, machinery, and equipment } \\
\text { purchases; and the construction of roads, railways, and } \\
\text { the like, including schools, offices, hospitals, private } \\
\text { residential dwellings, and commercial and industrial } \\
\text { buildings. Inventories are stocks of goods held by firms } \\
\text { to meet temporary or unexpected fluctuations in } \\
\text { production or sales, and 'work in progress.' }\end{array}$ & $\begin{array}{l}\text { World } \\
\text { database. }\end{array}$ & Bank \\
\hline $\begin{array}{l}\text { Human capital } \\
\text { development (\% of gross } \\
\text { enrolment) }\end{array}$ & $\begin{array}{l}\text { Measures secondary school enrolment as a ratio of total } \\
\text { enrolment, regardless of age, to the population of the } \\
\text { age group that officially corresponds to the level of } \\
\text { education shown. Secondary education completes the } \\
\text { provision of basic education that began at the primary } \\
\text { level, and aims at laying the foundations for lifelong } \\
\text { learning and human development, by offering more } \\
\text { subject- or skill-oriented instruction using more } \\
\text { specialized teachers. }\end{array}$ & $\begin{array}{l}\text { World } \\
\text { database. }\end{array}$ & Bank \\
\hline $\begin{array}{l}\text { Workforce (population } \\
\text { aged 15-64 as a } \\
\text { percentage of total) }\end{array}$ & $\begin{array}{l}\text { Used as a measure of a country's active population as a } \\
\text { ratio of total population. Total population between the } \\
\text { ages } 15 \text { to } 64 \text { is the number of people who could } \\
\text { potentially be economically active. Population is based } \\
\text { on the de facto definition of population, which counts } \\
\text { all residents regardless of legal status or citizenship-- } \\
\text { except for refugees not permanently settled in the } \\
\text { country of asylum, who are generally considered part of } \\
\text { the population of the country of origin. }\end{array}$ & $\begin{array}{l}\text { World } \\
\text { database. }\end{array}$ & Bank \\
\hline $\begin{array}{lr}\text { Foreign } & \text { Direct } \\
\text { Investment, } & \text { net } \\
\text { inflows }(\% G D P) & \end{array}$ & $\begin{array}{l}\text { FDI measures the sum of equity capital, reinvestment } \\
\text { of earnings, other long-term capital, and short-term } \\
\text { capital as shown in the balance of payments. This series } \\
\text { shows net inflows (new investment inflows less } \\
\text { disinvestment) in the reporting economy from foreign } \\
\text { investors, and is divided by GDP. }\end{array}$ & $\begin{array}{l}\text { World } \\
\text { database. }\end{array}$ & Bank \\
\hline
\end{tabular}

Source: Author's Compilation (2015)

The first stage is to do regression while treating all the variables as if they were exogenous by using the one stage within estimator and the Generalised Least Square. Subsequently, in the second stage of the regression, the trade openness is instrumented using the primary variables (i.e. $\log$ of economic location, log of GDP per capita, trade policy and $\log$ of population). The resultant equations are presented in the specifications below; 
GDP per capita growth ${ }_{i t}=\beta_{0}+\beta_{1} \log ($ initial conditions s $)+\beta_{2}\left(\right.$ Gross capital formation $\left.(\% G D P){ }_{i t}\right)+\beta_{s}($ Human capital

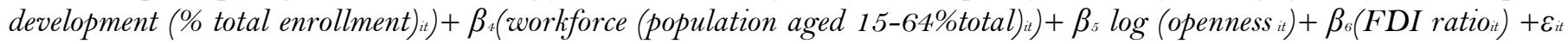
$(1.2)$

GDP per capita growth $=\beta_{0}+\beta_{1} \log \left(\right.$ initial conditions $\left.s_{i}\right)+\beta_{2}\left(\right.$ Gross capital formation $\left.(\% G D P)_{i t}\right)+\beta_{s}($ Human capital

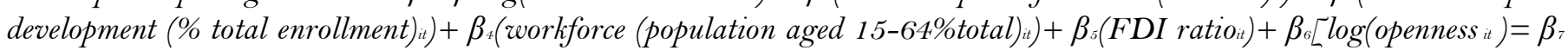
$\log ($ GDP per capita $i t)+\beta_{s} \log ($ economic location $i t)+\beta_{s} \log \left(\right.$ population $\left._{i}\right)+\beta_{10} \log \left(\right.$ area $\left._{i t}\right)+\beta_{1 t}$ trade policy $y_{i t}+\beta_{19}$ Agriculture $(\% G D P)+\beta_{1 s}$ Mining $\left.(\% G D P)\right]+\varepsilon_{i t}$

Where; openness it represents trade openness, $i$ is the $i$ th cross-section unit and $t$ is the time of observation, $\beta$ represents the coefficients of the variables and $\varepsilon_{i t}$ is the error term.

Table-2. Analysis of the Economic Growth of Sub Sahara Africa

\begin{tabular}{|c|c|c|c|c|}
\hline \multirow[b]{2}{*}{ Modelling Technique: } & \multicolumn{2}{|c|}{ One stage estimator (xtreg) } & \multicolumn{2}{|c|}{ Instrumented 2SLS (xtivreg) } \\
\hline & Fixed Effects & Random Effects & Fixed Effects & Random Effects \\
\hline \multirow[t]{2}{*}{ lninitial conditions } & 1.03 & 0.20 & 0.88 & 0.21 \\
\hline & $(0.98)$ & $(0.28)$ & $(1.00)$ & $(0.28)$ \\
\hline \multirow[t]{2}{*}{ Workforce } & 0.24 & $0.07 *$ & 0.23 & $0.06^{*}$ \\
\hline & $(0.19)$ & $(0.03)$ & $(0.19)$ & $(0.04)$ \\
\hline \multirow[t]{2}{*}{ Human capital (\% of total) } & 0.01 & 0.01 & 0.01 & 0.01 \\
\hline & $(0.03)$ & $(0.01)$ & $(0.03)$ & $(0.01)$ \\
\hline \multirow[t]{2}{*}{ Gross capital formation (\%GDP) } & $0.17 * * *$ & $0.14 * * *$ & $0.18^{*} * *$ & $0.16^{* * * *}$ \\
\hline & $(0.06)$ & $(0.03)$ & $(0.06)$ & $(0.04)$ \\
\hline \multirow[t]{2}{*}{ FDI flows (\%GDP) } & 0.05 & $0.15^{* * * *}$ & 0.06 & $0.13^{*}$ \\
\hline & $(0.09)$ & $(0.06)$ & $(0.09)$ & $(0.06)$ \\
\hline \multirow[t]{2}{*}{ Trade Openness } & 0.02 & $0.01^{*}$ & 0.05 & $0.02 *$ \\
\hline & $(0.01)$ & $(0.00)$ & $(0.03)$ & $(0.01)$ \\
\hline Hausman test & & $5.82(0.44)$ & & $5.72(0.45)$ \\
\hline R-square & 0.26 & 0.52 & 0.28 & 0.48 \\
\hline No. of Observations & 196 & 196 & 196 & 196 \\
\hline No of panel groups & 49 & 49 & 49 & 49 \\
\hline
\end{tabular}

Note: The dependent variable for these regression results is the GDP per capita growth. ${ }^{* * *},{ }^{* *},{ }^{*}$ denotes significance level at $1 \%, 5 \%$ and $10 \%$ respectively. Standard errors are in parentheses.

Table 2 presents the results for the specifications of the Equations 1.2 and 1.3. The Hausman test has been applied to decide on the two models, the fixed effects and the random effects. It is a test that tests the null hypothesis that the coefficients estimated by the efficient random effects estimator are the same as the ones estimated by the consistent fixed effects estimator. In this case the results shows that they are (that is insignificant, because the P-value, Prob>chi2 larger than the critical value .05) because the Prob>chi2 is 0.44 and 0.45 for one stage and instrumented 2SLS respectively. Therefore, for this specification, the Hausman test results in both cases do not reject the null hypothesis which means that the unique errors are not correlated with the regressors, hence the individual effects can adequately be modelled by a random effects model.

In both cases, gross capital formation and trade openness variables are highly significant, gross capital formation being highly significant (at 1\% level) and trade openness is significant at $10 \%$ in all cases. The FDI and the workforce variables are statistically significant in both cases under the random effect estimator. The workforce variable is only significant with the random effect estimator both in the first stage regression and in the instrumented G2SLS. This is consistent to the assertion that it is through a skilled workforce in the economy that foreign direct investment can have a positive effect on the economic growth (Borensztein et al., 1998). The Foreign direct investment (as percentage of GDP), is also highly statistically significant with the random effect model in the one stage estimation. All coefficients for these variables take their expected positive signs implying a positive effect on African economic growth (Alfaro et al., 2004).

The variable initial condition shows relatively lower coefficients and in both cases, it is not statistically significant, which suggests that the variable has lower influence on the economic growth. Likewise, the quality of human capital variables is not significant in all stages of both estimators. However, they take the expected signs in all four cases. FDI flows variable is not significant with the fixed effect estimator in both stages, in the same way the workforce variable is also not statistically significant, though all take the expected positive signs.

The R-square value shows that the explanatory variables together explain approximately $27 \%$ deviations in economic growth in model under the fixed effect estimator while it is approximately 50 per cent with the Generalised Least Square estimator. The estimated coefficients on trade openness are positively and significant at 1oper cent, indicating that an increase in the trade openness by one percent is associated with an increase in the economic growth of the African countries by 0.02 per cent. From the variables included in the growth model, the statistical results for both equations indicates that gross capital formation has more impact on economic growth for the African economies, followed by the level of openness and then FDI flows and the workforce (population aged $15-64)$ as a percentage of the total population.

Table 3 presents the alternative estimation using the instrumental variables and two stage least squares for panel data models using the "first" option. This option reports the variables in the model as well as the excluded instruments so that it is possible to examine the correlation of the instruments to the endogenous variable (i.e. trade openness). The first stage regression results above suggest that three of the seven excluded instruments are correlated with trade openness at different levels, the agriculture ratio is highly correlated followed by log of GDP per capita and mining ratio. 


\begin{tabular}{|c|c|c|}
\hline Modelling Technique: & First stage G2SLS regression & G2SLS random effect IV regression \\
\hline Initial conditions & $\begin{array}{l}0.06^{* * *} \\
(0.02)\end{array}$ & $\begin{array}{l}0.21 \\
(0.28)\end{array}$ \\
\hline Openness & & $\begin{array}{l}0.02^{*} \\
(0.01)\end{array}$ \\
\hline $\begin{array}{l}\text { Workforce (population. aged 15-64\% } \\
\text { total) }\end{array}$ & $\begin{array}{l}0.03 \\
(0.26)\end{array}$ & $\begin{array}{l}0.06^{*} \\
(0.03)\end{array}$ \\
\hline Human capital (\% of total) & $\begin{array}{l}0.14 \\
(0.10)\end{array}$ & $\begin{array}{l}0.01 \\
(0.01)\end{array}$ \\
\hline Gross capital formation (\%GDP) & $\begin{array}{l}-0.53^{* *} \\
(0.26)\end{array}$ & $\begin{array}{l}0.16^{* * *} \\
(0.04)\end{array}$ \\
\hline FDI flows $(\% G D P)$ & $\begin{array}{l}1.63^{* * * *} \\
(0.40)\end{array}$ & $\begin{array}{l}0.13^{* *} \\
(0.06)\end{array}$ \\
\hline InGDPper capita & $\begin{array}{l}-0.09 \\
(0.11)\end{array}$ & \\
\hline InPopulation & $\begin{array}{l}-0.21^{*} \\
(0.11)\end{array}$ & \\
\hline lnArea & $\begin{array}{l}-0.01 \\
(0.02)\end{array}$ & \\
\hline lneconomic location & $\begin{array}{l}0.07 \\
(0.11)\end{array}$ & \\
\hline Tradepolicy & $\begin{array}{l}0.01 \\
(0.02)\end{array}$ & \\
\hline Agriculture (\% GDP) & $\begin{array}{l}-0.58^{* * * *} \\
(0.17)\end{array}$ & \\
\hline Mining (\% GDP) & $\begin{array}{l}0.31^{*} \\
(0.18)\end{array}$ & \\
\hline No. of observation & 196 & 196 \\
\hline No. of panel groups & 49 & 49 \\
\hline
\end{tabular}

Note: The dependent variable for these regression results is the GDP per capita growth. ${ }^{* * *}{ }^{*} *{ }^{*}$ * denotes significance level at $1 \%, 5 \%$ and $10 \%$ respectively. Standard errors are in parentheses. The openness variable is instrumented by $\ln$ GDP per capita, lneconomic location, $\ln$ population, $\ln$ area, trade policy, Agriculture (\%GDP) and Mining(\%GDP).

The exceptions are the log of population and $\log$ of economic location and $\log$ of area. However it can be noted that conditioning on other variables included in the model, trade openness seem to play a relatively less role in determining the economic growth of the African countries. The rest of the variables present the same picture as discussed in Table 2 except for the initial conditions variable. These estimation results on the $\log$ of initial conditions shows that the variable is statistically significant and have relatively higher coefficients, implying a significant impact on economic growth in African countries. In any case the regression results indicate that trade openness and economic growth has positive relationship. Though the level of statistical significance is not that promising, still a positive relationship guarantees policy makers in the African countries that any effort to boost up trade levels in their economies will have desirable positive impacts on their economic growth rates.

\section{Further Examination on the Nature of Relationships and the Direction of Causality}

This part examines the existence of either uni or bi-directional causality between trade openness and economic growth. For this examination the extended sample period is used, from the previously used 1989 to 2008 now the sample period is 1980 to 2011 . The reason being the variables that are of interest do not have missing values as it was the case with some of the variables in the previous dataset.

The first step is to test the data to detect if they have any unit root, to ensure that they are stationary. This will ensure appropriate model specification and an avoidance of arriving at misleading results (Onafowora and Owoye, 1998). Only after establishing that the data for the variables are not stationary at level is when cointegration tests can be done. If the data for both variables are stationary this could mean that they are also cointegrated and therefore the necessity of running the short run causality tests to establish the direction of causality. The Granger causality test is conducted to establish the causality direction, the test aims at determining as to whether the variables have a unidirectional or bi directional causality.

\subsection{Unit Root Tests for Panel Data}

To conduct these tests the panel unit root tests are employed, which are essentially multiple series tests that have been applied to the panel data structures. The intention of testing for unit root aims at checking whether the data have their mean around zero.

There are various tests for testing the unit root in a dataset ranging from the Levin et al. (2002); Breitung (2001); Im et al. (2003) and Fisher type tests by Choi (2001). The study conducted all these tests to check for stationarity in the data. Despite the fact that the entire test gave same results, Table 4 reports only two unit root tests (Im, Pesaran and Shin and Fisher type). These tests allow heterogeneity, in the sense that they allow for different autoregressive (AR) structure for all of the series in the panel. Under this group, there are Im, Pesaran, Shin (IPS t- bar tests) by Im et al. (2003) and Fisher-type by Choi (2001). These tests are both referred to as unit root tests with individual unit root processes, they has as the null hypothesis that all the panels have a unit root (Choi, 2001; Breitung, 2002; Levin et al., 2002; Im et al., 2003). 
The choice of these two tests is also based on the nature of data, while their counterparts assume panels of data are balanced and therefore cannot be applied in a situation of unbalanced panel data, Im, Pesaran and Shin and Fisher type tests have proved to work perfectly with the unbalanced data panels, though there cannot be gaps in a panel. They are therefore chosen because the panel dataset in use involves a large number of African countries which in most cases does not have all the data for the whole sample period. These tests also have been recommended as performing well in combining individual unit root tests applied on each time series when the panel data that are heterogeneous and non-stationary are used. They thus derive the panel specific unit root from combining of individual unit root tests.

The Fisher type tests are devised for finite $N$ as well as infinite $N$; they assume that each individual panel has different types of non-stochastic and stochastic component; and that the time series span are different for each of the panels. Both test settings, assume that the alternative hypothesis is that some of the panels have a unit root while other panels does not. Under the Fisher type tests settings, the main idea is to combine p-values from the unit root tests applied to each panel. For IPS $t$-bar test is a t-bar statistic based on the augmented Dickey-Fuller statistic (Dickey and Fuller, 1979) the test statistic is computed by the sample mean of the individual unit root tests for each panel. Therefore, while both tests combine information based on individual unit root tests, the crucial difference between the two is that the IPS test is based on combining the test statistics while the Fisher-type test is based on combining the significance levels of the individual tests (Maddala and $\mathrm{Wu}, 1999$ ).

\section{The Framework}

Consider a sample of $N$ cross sections (i.e. countries) observed over $T$ time periods (1980-2011). The stochastic process, $y_{i t}$, is generated by the first-order autoregressive process:

Where;

$$
y_{i t}=\left(1-\emptyset_{i}\right) \mu_{i}+\varnothing_{i} y_{i t-1}+\varepsilon_{i t}, \quad I=1, \ldots N, t=1, \ldots, T,
$$

Initial values, $y_{i o}$, are given. The interest is in testing the null hypothesis of unit roots $\emptyset_{i}=1$ for all $i$.

The Equation (1.4) above can be expressed as;

$$
d y_{i t}=\alpha_{i}+\beta_{i} y_{i t-l}+\varepsilon_{i t}
$$

Where; $\alpha_{i}=\left(1-\emptyset_{i}\right) \mu_{i}, \beta_{i}=-\left(1-\emptyset_{i}\right)$ and $d y_{i t}=y_{i t-} y_{i t-1}$

\begin{tabular}{|c|c|c|c|c|c|c|c|}
\hline & \multicolumn{2}{|l|}{ IPS } & \multicolumn{2}{|c|}{ Fisher - ADF } & \multicolumn{2}{|c|}{ Fisher - PP } & \multirow[t]{2}{*}{ Conclusion } \\
\hline & Intercept & $\begin{array}{l}\text { Intercept } \\
\text { and trend }\end{array}$ & Intercept & $\begin{array}{l}\text { Intercept } \\
\text { and trend }\end{array}$ & Intercept & $\begin{array}{l}\text { Intercept } \\
\text { and trend }\end{array}$ & \\
\hline Openness & $\begin{array}{l}-2.55^{* * * *} \\
(0.00)\end{array}$ & $\begin{array}{l}-4.21^{* * * *} \\
(0.00)\end{array}$ & $\begin{array}{l}159.37^{* * * *} \\
(0.00)\end{array}$ & $\begin{array}{l}194.15^{\text {**** }} \\
(0.00)\end{array}$ & $\begin{array}{l}145.49^{* * * *} \\
(0.00)\end{array}$ & $\begin{array}{l}169.87^{* * * *} \\
(0.00)\end{array}$ & $\mathrm{I}(\mathrm{O})$ \\
\hline GDPpp growth & $\begin{array}{l}-21.31^{* * * *} \\
(0.00)\end{array}$ & $\begin{array}{l}-22.04^{* * * *} \\
(0.00)\end{array}$ & $\begin{array}{l}735.05^{* * * *} \\
(0.00)\end{array}$ & $\begin{array}{l}757.76^{\text {**** }} \\
(0.00)\end{array}$ & $\begin{array}{l}910.26^{* * * *} \\
(0.00)\end{array}$ & $\begin{array}{l}1461.92^{* * * *} \\
(0.00)\end{array}$ & $\mathrm{I}(\mathrm{O})$ \\
\hline FDI (\% GDP) & $\begin{array}{l}-10.68^{* * * *} \\
(0.00)\end{array}$ & $\begin{array}{l}-10.19^{* * * *} \\
(0.00)\end{array}$ & $\begin{array}{l}375.87^{* * * *} \\
(0.00)\end{array}$ & $\begin{array}{l}354.04^{* * * *} \\
(0.00)\end{array}$ & $\begin{array}{l}390.34^{* * * *} \\
(0.00)\end{array}$ & $\begin{array}{l}346.52^{* * * *} \\
(0.00)\end{array}$ & $\mathrm{I}(\mathrm{O})$ \\
\hline $\begin{array}{l}\text { Gross Capital } \\
\text { Formation }(\% \\
\text { GDP) }\end{array}$ & $\begin{array}{l}-4.45^{* * * *} \\
(0.00)\end{array}$ & $\begin{array}{l}-3.39^{* * * *} \\
(0.00)\end{array}$ & $\begin{array}{l}212.81^{* * * *} \\
(0.00)\end{array}$ & $\begin{array}{l}230.04^{* * * *} \\
(0.00)\end{array}$ & $\begin{array}{l}189.93^{*} * * \\
(0.00)\end{array}$ & $\begin{array}{l}162.08^{* * *} * \\
(0.00)\end{array}$ & $\mathrm{I}(\mathrm{O})$ \\
\hline $\begin{array}{l}\text { Quality of } \\
\text { Human Capital } \\
(\% \text { of total) }\end{array}$ & $\begin{array}{l}-9.62 \text { **** } \\
(0.00)\end{array}$ & $\begin{array}{l}-6.92^{* * * *} \\
(0.00)\end{array}$ & $\begin{array}{l}299.92^{* * * *} \\
(0.00)\end{array}$ & $\begin{array}{l}239.51^{* * * *} \\
(0.00)\end{array}$ & $\begin{array}{l}\text { 332.39*** } \\
(0.00)\end{array}$ & $\begin{array}{l}336.37^{* * * *} \\
(0.00)\end{array}$ & $\mathrm{I}(\mathrm{O})$ \\
\hline $\begin{array}{l}\text { Workforce } \\
\text { (aged } 15-64 \% \\
\text { total population) }\end{array}$ & $\begin{array}{l}-3.15^{* * * *} \\
(0.00)\end{array}$ & $\begin{array}{l}14.03 \\
(1.00)\end{array}$ & $\begin{array}{l}184.15^{* * * *} \\
\text { (0.00) }\end{array}$ & $\begin{array}{l}58.68 \\
(1.00)\end{array}$ & $\begin{array}{l}110.92 \\
(0.51)\end{array}$ & $\begin{array}{l}16.05 \\
(1.00)\end{array}$ & $\mathrm{I}(\mathrm{O})$ \\
\hline
\end{tabular}

Table-4. Panel Unit root Tests Results 1980 -2011(by using Im, Pesaran and Shin test, and Fisher type test).

root at the $1 \%$ significance level. Probabilities in parentheses.

The null hypothesis of the unit roots then becomes;

$$
H_{o}: \beta_{i}=O \text { for all } i
$$

Against the alternatives that allows for some of the cross section in the panel to have unit roots (i.e. at least one is stationary),

$$
H_{1:} \beta_{i}<0, \quad i=1,2, \ldots, N_{l}, \quad \beta_{i}=0, \quad i=N_{\imath}+1, N_{t}+2, \ldots, N .
$$

The formulation of this alternative hypothesis allows $\beta_{i}$ to differ across cross sections, hence allowing for heterogeneity.

Table 4 presents the results for the unit root test for all the variables of interest in both level and in first difference. The table presents only two unit root tests, but it is good to note as mentioned earlier that the test was done using all the unit root tests mentioned above. The results for all the tests were the same, that is, all the variables were stationary at level. Therefore, this shows that despite the choice of the two tests, the data are proved to behave in the same way with the other unit root tests as well.

The results show that for all variables both IPS and Fisher type tests for unit roots reject the null hypothesis of non-stationary at level. For that reason, the tests results do reject the null hypothesis of non-stationary at level with both individual effect and individual linear trend effects. By the fact that both variables are rejecting the null hypothesis at the order of $\mathrm{I}(0)$, it means that trade openness and economic growth (as measured by GDP per capita) are integrated to the order of one $\mathrm{I}(\mathrm{O})$. Since they are integrated of the same order, it also means that they are cointegrated as well. 


\subsection{Panel Granger Causality Test}

So far, the relationships that exist between the variables have been established; however the existing relationship does not prove anything on the causality or direction of influence. A common sense logic of causality may start from the axiom that, time always forge ahead, never backward (Koop, 2000). Thus, since a certain event A happened before event $\mathrm{B}$, one can conclude fallaciously that there is a possibility that event A caused the happening of event B (i.e. past events can cause the current events). But sometimes both the variables A and B fail to Granger cause each other, in this case they are said to be independent variables. There is also a possibility that $\mathrm{A}$ Granger causes B, meanwhile B Granger causes A (this is referred to as bi-directional causality).

Under Granger causality, if variable A (Granger) causes variable B, then changes in A must precede changes in $\mathrm{B}$. Hence when regressing $\mathrm{B}$ on other variables (including the past values of $\mathrm{B}$ ) if the lagged values of $\mathrm{A}$ are included and they improves the prediction of B, then it can be concluded that A (Granger) causes B. Similar case will be for the case where B (Granger) causes A.

The main idea under this test is to predict the existence and direction of causality; whether it is running from trade openness to GDP per capita or from GDP per capita to trade openness, or runs from both directions (bi directional). This is known as bilateral causality as there are only two variables under consideration, in case where more than two variables are involved, hence multivariable causation, the relevant technique would be the Vector Autoregression (VAR). Granger causality test involves the estimation of the following pair of regressions:

$$
\begin{aligned}
& y_{i, t}=\alpha_{1, t}+\sum_{l=1}^{m l y_{i}} \beta_{1, i, l} y_{i, t-l}+\sum_{l-i}^{m l x_{i}} \gamma_{1, i, l} x_{i, t-l}+\varepsilon_{1, i, t} \\
& x_{i, t}=\alpha_{2, t}+\sum_{l=1}^{m l y_{i}} \beta_{2, i, l} y_{i, t-l}+\sum_{l-i}^{m l x_{i}} \gamma_{2, i, l} x_{i, t-l}+\varepsilon_{2, i, t}
\end{aligned}
$$

Where; index $i$ refers to the country $(i=1, \ldots, N), t$ to the time period $(t=1, \ldots, T)$ and $l$ to the lag. $\varepsilon_{1, i, t}$ ,$\varepsilon_{2, i, t}$ represents the white noise errors that may be correlated for a given country but not across countries. It is also assumed that $y_{t}$ and $x_{t}$ are stationary or cointegrated and in this case at first difference of GDP per capita and trade openness respectively.

With respect to this method, in country $i$ there is one way Granger causality running from $X$ to $Y$ if in the first equation not all $\gamma_{1, i}$ 's are zero but in the second all $\beta_{2, i}$ 's (regression coefficients) are zero, there is one way Granger causality from $\mathrm{Y}$ to $\mathrm{X}$ if in the first equation all $\gamma_{1, i}$ 's (autoregressive coefficients)are zero but in the second not all $\beta_{2, i}$ 's are zero, there is two way Granger causality between $\mathrm{Y}$ and $\mathrm{X}$ if neither all $\beta_{2, i}$ 's nor all $\gamma_{1, i}$ 's, are zero, and there is no Granger causality between $\mathrm{Y}$ and $\mathrm{X}$ if all $\beta_{2, i}$ 's and $\gamma_{1, i}$ 's are zero. The evaluation of the null hypothesis that $x$ does not Granger cause $y$ can be done by estimating an equation in which $y$ is regressed on lagged values of $y$ and the lagged values of an additional variable $x$. To reject the null hypothesis that $x$ does not Granger cause $y$ (i.e. concluding that $x$ Granger cause $y$ ), one or more of the lagged values of $x$ must be significant. Despite the fact that Granger causality tool has been considered to be imperfect, it is, yet a standard and helpful tool for assessing the causality relationship between two variables.

The most reported weakness of the panel Granger tests despite their advantages is the inappropriate assumption of causal homogeneity. Of course, this is true for most of the panel data analysis, the flaw of making inferences on causal relationships in all individual cross section units while it sometimes exists in only some of the individual cross sections. This may as well be true on the other way round, rejecting the existence of causality for the whole group of cross section individuals while actually there exists some causal relationships in some of the individual cross sections in the panel.

However, it is also good to note that the outcome of the Granger test is sensitive to the number of lags introduced in the regression model. This is because too few or too many lags are problematic, too few lags means some important variables are omitted hence specification error that leads to biasness in the retained regression coefficients, leading to erroneous conclusions. Likewise too many lags leads to specification error indicating wasteful observations, hence increasing the standard errors of the estimated coefficients leading to false conclusions (Konya 2006). The results in the Table 5 are based on the lag of 2 , however whatever lag that could be chosen between 1 to 10 gives the same results in terms of significance and the nature of causality.

Table-5. Short run causality test by Granger

\begin{tabular}{l|l|l}
\hline Dependent variables & Source of Causation (independent variables) \\
\hline & Trade openness & GDP per capita growth \\
\hline & F - Statistic (p- value) & $\begin{array}{l}8.21^{* * *} \\
(0.00)\end{array}$ \\
\hline Trade openness & - & - \\
\hline GDP per capita growth & 0.03 & \\
\hline
\end{tabular}
and, ** Rejects the null of non-causality at the $5 \%$ significance level.

The short-run causality tests by using Granger reveal that there exists a high statistical significant unidirectional short run causal relationship between trade openness and GDP per capita growth. The direction of causality runs from economic growth to trade openness indicating that economic growth induces trade flows in Africa. This implies that African countries could boost their trade openness ratios by enhancing their economic development. The results supports growth led hypothesis for the African countries.

The results above do not give the detailed Granger causality for the variables for each individual African country. It is inevitable to have a look on the detailed individual African countries considering the fact that most of these countries significantly differ from one another, so they could have different economic growth experiences and hence the causality directions between trade openness and economic growth. Factors such as civil wars in some of these countries, different extent of foreign aid they receive, the differences in climatic conditions, and differences in natural resources endowments, among others, explains for the economic disparities among African countries. 
However for this to be done requires a cross section data analysis rather than the previously used panel dataset. The sample size is altered as four countries (Djibouti, Libya, Somalia and Eritrea) were removed from the sample due to many gaps in the data as a result of which the Granger causality test could not workout. It is expected that testing for Granger causality for each country in the sample will also help to explain the differences between countries. Table 6 shows mixed results for the different African countries.

Table-6. Granger causality Wald tests for individual African countries (Lags 5)

\begin{tabular}{|c|c|c|}
\hline Null Hypothesis & F-statistic & Probability \\
\hline $\begin{array}{l}\text { Algeria's lagged values of trade openness does not Granger cause GDP per } \\
\text { capita growth }\end{array}$ & 0.8011 & 0.5641 \\
\hline $\begin{array}{l}\text { Algeria's lagged values of GDP per capita growth does not Granger cause } \\
\text { trade openness }\end{array}$ & 1.6771 & 0.1940 \\
\hline $\begin{array}{l}\text { Angola's lagged values of trade openness does not Granger cause GDP per } \\
\text { capita growth }\end{array}$ & 2.5879 & 0.0944 \\
\hline $\begin{array}{l}\text { Angola's lagged values of GDP per capita growth does not Granger cause } \\
\text { trade openness }\end{array}$ & 4.9693 & 0.0149 \\
\hline $\begin{array}{l}\text { Benin's lagged values of trade openness does not Granger cause GDP per } \\
\text { capita growth }\end{array}$ & 2.0173 & 0.1276 \\
\hline $\begin{array}{l}\text { Benin's lagged values of GDP per capita growth does not Granger cause } \\
\text { trade openness }\end{array}$ & 1.5083 & 0.2393 \\
\hline $\begin{array}{l}\text { Botswana's lagged values of trade openness does not Granger cause GDP per } \\
\text { capita growth }\end{array}$ & 2.8533 & 0.0493 \\
\hline $\begin{array}{l}\text { Botswana's lagged values of GDP per capita growth does not Granger cause } \\
\text { trade openness }\end{array}$ & 3.4521 & 0.0256 \\
\hline $\begin{array}{l}\text { Burkina Faso's lagged values of trade openness does not Granger cause GDP } \\
\text { per capita growth }\end{array}$ & 2.877 & 0.0480 \\
\hline $\begin{array}{l}\text { Burkina Faso's lagged values of GDP per capita growth does not Granger } \\
\text { cause trade openness }\end{array}$ & 0.33131 & 0.8538 \\
\hline $\begin{array}{l}\text { Burundi's lagged values of trade openness does not Granger cause GDP per } \\
\text { capita growth }\end{array}$ & 1.1316 & 0.3794 \\
\hline $\begin{array}{l}\text { Burundi's lagged values of GDP per capita growth does not Granger cause } \\
\text { trade openness }\end{array}$ & 0.10774 & 0.9892 \\
\hline $\begin{array}{l}\text { Cameroon's lagged values of trade openness does not Granger cause GDP } \\
\text { per capita growth }\end{array}$ & 3.3337 & 0.0264 \\
\hline $\begin{array}{l}\text { Cameroon's lagged values of GDP per capita growth does not Granger cause } \\
\text { trade openness }\end{array}$ & 0.62039 & 0.6861 \\
\hline $\begin{array}{l}\text { Central Africa Republic's lagged values of trade openness does not Granger } \\
\text { cause GDP per capita growth }\end{array}$ & 1.6074 & 0.2095 \\
\hline $\begin{array}{l}\text { Central Africa Republic's lagged values of GDP per capita growth does not } \\
\text { Granger cause trade openness }\end{array}$ & 2.3836 & 0.0840 \\
\hline $\begin{array}{l}\text { Chad's lagged values of trade openness does not Granger cause GDP per } \\
\text { capita growth }\end{array}$ & 4.4836 & 0.0079 \\
\hline $\begin{array}{l}\text { Chad's lagged values of GDP per capita growth does not Granger cause trade } \\
\text { openness }\end{array}$ & 0.15731 & 0.9750 \\
\hline $\begin{array}{l}\text { Congo's lagged values of trade openness does not Granger cause GDP per } \\
\text { capita growth }\end{array}$ & 2.4155 & 0.0765 \\
\hline $\begin{array}{l}\text { Congo's lagged values of GDP per capita growth does not Granger cause } \\
\text { trade openness }\end{array}$ & 0.83672 & 0.5408 \\
\hline $\begin{array}{l}\text { Cote d'Ivoire's lagged values of trade openness does not Granger cause GDP } \\
\text { per capita growth }\end{array}$ & 8.2656 & 0.0003 \\
\hline $\begin{array}{l}\text { Cote d'Ivoire's lagged values of GDP per capita growth does not Granger } \\
\text { cause trade openness }\end{array}$ & 0.47718 & 0.7885 \\
\hline $\begin{array}{l}\text { D.R.C's lagged values of trade openness does not Granger cause GDP per } \\
\text { capita growth }\end{array}$ & 0.56938 & 0.7225 \\
\hline $\begin{array}{l}\text { D.R.C's lagged values of GDP per capita growth does not Granger cause } \\
\text { trade openness }\end{array}$ & 0.32143 & 0.8935 \\
\hline $\begin{array}{l}\text { Djibouti’s lagged values of trade openness does not Granger cause GDP per } \\
\text { capita growth }\end{array}$ & 2.9518 & 0.0693 \\
\hline $\begin{array}{l}\text { Djibouti's lagged values of GDP per capita growth does not Granger cause } \\
\text { trade openness }\end{array}$ & 0.53504 & 0.5917 \\
\hline $\begin{array}{l}\text { Egypt's lagged values of trade openness does not Granger cause GDP per } \\
\text { capita growth }\end{array}$ & 3.429 & 0.0237 \\
\hline $\begin{array}{l}\text { Egypt's lagged values of GDP per capita growth not Granger cause trade } \\
\text { openness }\end{array}$ & 0.5152 & 0.7614 \\
\hline $\begin{array}{l}\text { Equatorial Guinea's lagged values of trade openness does not Granger cause } \\
\text { GDP per capita growth }\end{array}$ & 8.0177 & 0.0004 \\
\hline $\begin{array}{l}\text { Equatorial Guinea's lagged values of GDP per capita growth does not } \\
\text { Granger cause trade openness }\end{array}$ & 4.3112 & 0.0094 \\
\hline $\begin{array}{l}\text { Eritrea's lagged values of trade openness does not Granger cause GDP per } \\
\text { capita growth }\end{array}$ & 7.083 & 0.0008 \\
\hline
\end{tabular}




\begin{tabular}{|c|c|c|}
\hline $\begin{array}{l}\text { Eritrea's lagged values of GDP per capita growth does not Granger cause } \\
\text { trade openness }\end{array}$ & 0.61825 & 0.6876 \\
\hline $\begin{array}{l}\text { Ethiopia's lagged values of trade openness does not Granger cause GDP per } \\
\text { capita growth }\end{array}$ & 5.8085 & 0.0023 \\
\hline $\begin{array}{l}\text { Ethiopia's lagged values of GDP per capita growth does not Granger cause } \\
\text { trade openness }\end{array}$ & 0.89956 & 0.5025 \\
\hline $\begin{array}{l}\text { Gabon's lagged values of trade openness does not Granger cause GDP per } \\
\text { capita growth }\end{array}$ & 8.8078 & 0.0011 \\
\hline $\begin{array}{l}\text { Gabon's lagged values of GDP per capita growth does not Granger cause } \\
\text { trade openness }\end{array}$ & 0.58228 & 0.5655 \\
\hline $\begin{array}{l}\text { Gambia's lagged values of trade openness does not Granger cause GDP per } \\
\text { capita growth }\end{array}$ & 1.7701 & O.1699 \\
\hline $\begin{array}{l}\text { Gambia's lagged values of GDP per capita growth does not Granger cause } \\
\text { trade openness }\end{array}$ & 0.45545 & 0.8039 \\
\hline $\begin{array}{l}\text { Ghana's lagged values of trade openness does not Granger cause GDP per } \\
\text { capita growth }\end{array}$ & 0.71634 & 0.4976 \\
\hline $\begin{array}{l}\text { Ghana's lagged values of GDP per capita growth does not Granger cause } \\
\text { trade openness }\end{array}$ & 3.7343 & 0.0370 \\
\hline $\begin{array}{l}\text { Guinea's lagged values of trade openness does not Granger cause GDP per } \\
\text { capita growth }\end{array}$ & 1.5138 & 0.2349 \\
\hline $\begin{array}{l}\text { Guinea's lagged values of GDP per capita growth does not Granger cause } \\
\text { trade openness }\end{array}$ & 3.4525 & 0.0231 \\
\hline $\begin{array}{l}\text { Guinea Bissau's lagged values of trade openness does not Granger cause } \\
\text { GDP per capita growth }\end{array}$ & 3.2331 & 0.0551 \\
\hline $\begin{array}{l}\text { Guinea Bissau's lagged values of GDP per capita growth does not Granger } \\
\text { cause trade openness }\end{array}$ & 0.28378 & 0.7552 \\
\hline $\begin{array}{l}\text { Kenya's lagged values of trade openness does not Granger cause GDP per } \\
\text { capita growth }\end{array}$ & 0.53149 & 0.7497 \\
\hline $\begin{array}{l}\text { Kenya's lagged values of GDP per capita growth does not Granger cause } \\
\text { trade openness }\end{array}$ & 2.9601 & 0.0402 \\
\hline $\begin{array}{l}\text { Lesotho's lagged values of trade openness does not Granger cause GDP per } \\
\text { capita growth }\end{array}$ & 1.3394 & 0.2927 \\
\hline $\begin{array}{l}\text { Lesotho's lagged values of GDP per capita growth does not Granger cause } \\
\text { trade openness }\end{array}$ & 0.92489 & 0.4877 \\
\hline $\begin{array}{l}\text { Liberia's lagged values of trade openness does not Granger cause GDP per } \\
\text { capita growth }\end{array}$ & 0.51435 & 0.7620 \\
\hline $\begin{array}{l}\text { Liberia's lagged values of GDP per capita growth does not Granger cause } \\
\text { trade openness }\end{array}$ & 0.20799 & 0.9548 \\
\hline $\begin{array}{l}\text { Libya's lagged values of trade openness does not Granger cause GDP per } \\
\text { capita growth }\end{array}$ & 2.8313 & 0.0765 \\
\hline $\begin{array}{l}\text { Libya's lagged values of GDP per capita growth does not Granger cause } \\
\text { trade openness }\end{array}$ & 0.23857 & 0.7894 \\
\hline $\begin{array}{l}\text { Madagascar's lagged values of trade openness does not Granger cause GDP } \\
\text { per capita growth }\end{array}$ & 0.62897 & 0.6800 \\
\hline $\begin{array}{l}\text { Madagascar's lagged values of GDP per capita growth does not Granger } \\
\text { cause trade openness }\end{array}$ & 0.6291 & 0.6799 \\
\hline $\begin{array}{l}\text { Malawi's lagged values of trade openness does not Granger cause GDP per } \\
\text { capita growth }\end{array}$ & 2.5274 & 0.0986 \\
\hline $\begin{array}{l}\text { Malawi's lagged values of GDP per capita growth does not Granger cause } \\
\text { trade openness }\end{array}$ & 3.0928 & 0.0617 \\
\hline $\begin{array}{l}\text { Mauritania's lagged values of trade openness does not Granger cause GDP } \\
\text { per capita growth }\end{array}$ & 1.294 & 0.3099 \\
\hline $\begin{array}{l}\text { Mauritania's lagged values of GDP per capita growth does not Granger cause } \\
\text { trade openness }\end{array}$ & 1.4456 & 0.2560 \\
\hline $\begin{array}{l}\text { Mauritius's lagged values of trade openness does not Granger cause GDP per } \\
\text { capita growth }\end{array}$ & 2.5067 & 0.0686 \\
\hline $\begin{array}{l}\text { Mauritius's lagged values of GDP per capita growth does not Granger cause } \\
\text { trade openness }\end{array}$ & 2.275 & 0.0907 \\
\hline $\begin{array}{l}\text { Morocco's lagged values of trade openness does not Granger cause GDP per } \\
\text { capita growth }\end{array}$ & 3.7011 & 0.0380 \\
\hline $\begin{array}{l}\text { Morocco's lagged values of GDP per capita growth does not Granger cause } \\
\text { trade openness }\end{array}$ & 0.55158 & 0.5824 \\
\hline $\begin{array}{l}\text { Mozambique's lagged values of trade openness does not Granger cause GDP } \\
\text { per capita growth }\end{array}$ & 0.96555 & 0.4646 \\
\hline $\begin{array}{l}\text { Mozambique's lagged values of GDP per capita growth does not Granger } \\
\text { cause trade openness }\end{array}$ & 0.5234 & 0.7555 \\
\hline $\begin{array}{l}\text { Namibia's lagged values of trade openness does not Granger cause GDP per } \\
\text { capita growth }\end{array}$ & 6.4002 & 0.0053 \\
\hline $\begin{array}{l}\text { Namibia's lagged values of GDP per capita growth does not Granger cause } \\
\text { trade openness }\end{array}$ & 0.69089 & 0.5098 \\
\hline
\end{tabular}




\begin{tabular}{|c|c|c|}
\hline $\begin{array}{l}\text { Niger's lagged values of trade openness does not Granger cause GDP per } \\
\text { capita growth }\end{array}$ & 4.4979 & 0.0078 \\
\hline $\begin{array}{l}\text { Niger's lagged values of GDP per capita growth does not Granger cause } \\
\text { trade openness }\end{array}$ & 2.5816 & 0.0627 \\
\hline $\begin{array}{l}\text { Nigeria's lagged values of trade openness does not Granger cause GDP per } \\
\text { capita growth }\end{array}$ & 4.1374 & 0.0112 \\
\hline $\begin{array}{l}\text { Nigeria's lagged values of GDP per capita growth does not Granger cause } \\
\text { trade openness }\end{array}$ & 0.10042 & 0.9908 \\
\hline $\begin{array}{l}\text { Rwanda's lagged values of trade openness does not Granger cause GDP per } \\
\text { capita growth }\end{array}$ & 3.2247 & 0.0298 \\
\hline $\begin{array}{l}\text { Rwanda's lagged values of GDP per capita growth not Granger cause trade } \\
\text { openness }\end{array}$ & 6.0261 & 0.0019 \\
\hline $\begin{array}{l}\text { Senegal's lagged values of trade openness does not Granger cause GDP per } \\
\text { capita growth }\end{array}$ & 2.3085 & 0.0871 \\
\hline $\begin{array}{l}\text { Senegal's lagged values of GDP per capita growth does not Granger cause } \\
\text { trade openness }\end{array}$ & 1.6112 & 0.2077 \\
\hline $\begin{array}{l}\text { Seychelles' s lagged values of trade openness does not Granger cause GDP } \\
\text { per capita growth }\end{array}$ & 1.2395 & 0.3318 \\
\hline $\begin{array}{l}\text { Seychelles' lagged values of GDP per capita growth does not Granger cause } \\
\text { trade openness }\end{array}$ & 7.5168 & 0.0006 \\
\hline $\begin{array}{l}\text { Sierra Leone's lagged values of trade openness does not Granger cause GDP } \\
\text { per capita growth }\end{array}$ & 2.3715 & 0.0807 \\
\hline $\begin{array}{l}\text { Sierra Leone's lagged values of GDP per capita growth does not Granger } \\
\text { cause trade openness }\end{array}$ & 0.95221 & 0.4721 \\
\hline $\begin{array}{l}\text { Sudan's lagged values of trade openness does not Granger cause GDP per } \\
\text { capita growth }\end{array}$ & 1.0108 & 0.4399 \\
\hline $\begin{array}{l}\text { Sudan's lagged values of GDP per capita growth does not Granger cause } \\
\text { trade openness }\end{array}$ & 1.0854 & 0.4016 \\
\hline $\begin{array}{l}\text { Tanzania's lagged values of trade openness does not Granger cause GDP per } \\
\text { capita growth }\end{array}$ & 3.939 & 0.0137 \\
\hline $\begin{array}{l}\text { Tanzania's lagged values of GDP per capita growth does not Granger cause } \\
\text { trade openness }\end{array}$ & 1.0992 & 0.3949 \\
\hline $\begin{array}{l}\text { Togo's lagged values of trade openness does not Granger cause GDP per } \\
\text { capita growth }\end{array}$ & 0.80132 & 0.4591 \\
\hline $\begin{array}{l}\text { Togo's lagged values of GDP per capita growth does not Granger cause } \\
\text { trade openness }\end{array}$ & 0.45999 & 0.6361 \\
\hline $\begin{array}{l}\text { Tunisia's lagged values of trade openness does not Granger cause GDP per } \\
\text { capita growth }\end{array}$ & 1.4625 & 0.2506 \\
\hline $\begin{array}{l}\text { Tunisia's lagged values of GDP per capita growth does not Granger cause } \\
\text { trade openness }\end{array}$ & 5.0319 & 0.0047 \\
\hline $\begin{array}{l}\text { Uganda's lagged values of trade openness does not Granger cause GDP per } \\
\text { capita growth }\end{array}$ & 5.1588 & 0.0047 \\
\hline $\begin{array}{l}\text { Uganda's lagged values of GDP per capita growth does not Granger cause } \\
\text { trade openness }\end{array}$ & 0.94342 & 0.4584 \\
\hline $\begin{array}{l}\text { Zambia's lagged values of trade openness does not Granger cause GDP per } \\
\text { capita growth }\end{array}$ & 3.9071 & 0.0323 \\
\hline $\begin{array}{l}\text { Zambia's lagged values of GDP per capita growth does not Granger cause } \\
\text { trade openness }\end{array}$ & 0.04414 & 0.9569 \\
\hline $\begin{array}{l}\text { Zimbabwe's lagged values of trade openness does not Granger cause GDP } \\
\text { per capita growth }\end{array}$ & 5.7073 & 0.0025 \\
\hline $\begin{array}{l}\text { Zimbabwe's lagged values of GDP per capita growth does not Granger cause } \\
\text { trade openness }\end{array}$ & 4.8202 & 0.0057 \\
\hline
\end{tabular}

In fact the dominant hypothesis for the 34.8 per cent of the African countries in the sample is the export led growth hypothesis. This group is a composition of 16 countries (Burkina Faso, Cameroon, Chad, and Cot d'Ivoire, Egypt, Eritrea, Ethiopia, Gabon, Guinea Bissau, Morocco, Namibia, Niger, Nigeria, Tanzania, Uganda and Zambia). Several studies have recommended this hypothesis than any other particularly for the developing countries like most of the African countries. This is based on the fact that with the export promotion hypothesis African countries can expand their limited domestic markets by making use of the international markets through exports of their products (Chow, 1987). However the export led hypothesis would be much more advantageous for the African countries if it would not only result into increased in real incomes but also if it would result into economic structural transformation of these economies.

This is important because in order for these countries to achieve sustained economic growths, promotion of trade openness presupposes a well-established set of institutions and investment strategies. The importance of having well established domestic institutions and investments strategies lies on the fact that the world has been facing several international economic problems. One of which is the increasing protectionism especially for developed countries which has effects on the developing countries trying to open up their economies. Studies show that the collapse of the world trade (by US $\$ 43$ billion) during the 2008 crisis was as a result of increased tariffs on 
major imported products in Russia, China, Argentina and Turkey. It was also due to higher antidumping duties in the United States and the EU (Kee et al., 2013).

Most of these economies impose restrictions on the free flow of trade on the grounds of national welfare, while they are advocated by and greatly for the benefit of small minority of producers in the economy at the expense of mostly silent majority of consumers (Salvatore, 1998). It is even more challenging with the tendency of the world to break up in three major blocks, a North American block (i.e. US, Canada and Mexico), a European trading block and Asian trading block. With these tendency towards protectionism by developed economies and the creation of blocks, poor African economies are left hanging, even in their efforts to adopt openness strategies so as to boost their economies proves futile.

There is also an excessive volatility of exchange rates as a challenge facing international economics. The pattern of international trade and specialisation is greatly affected by large fluctuations of national currencies as well as persistent exchange rates disequilibrium. Besides it causes the instability in global international financial conditions. For unstable economies with feeble domestic financial and institutional system like the African economies, opening up to the world market may be disastrous leading a country into experiencing disadvantages of openness.

Granger Causality results in Table 6 also indicate that 13.0 per cent of the African economies in the sample show preference of growth led hypothesis. Countries in this group include Angola, Ghana, Guinea, Kenya, Seychelles and Tunisia; whereas only 8.7 per cent indicates a bi directional causality between trade openness and economic growth.

For these countries the implication is that trade openness and economic growth are mutually beneficial and reinforce each other (Chow, 1987; Klasra, 2011). The results also indicate a large number of countries with no conclusive implication for causality direction. For these countries which represent 43.5 percent of the sample, the implication could be that the adoption of other strategies other than export led or growth led hypothesis might result into economic growth (Sarkar, 2008).

\section{Conclusions}

This paper has examined the effects of trade openness on economic growth for the African countries; this has been done by use of growth models and later Granger causality analysis. From the variables included in the growth model, the statistical results indicates that gross capital formation has more impact on economic growth for the African economies, followed by the level of openness and then FDI flows and the workforce (population aged 15$64)$ as a percentage of the total population. Moreover, the regression results indicate that trade openness and economic growth has positive relationship. Though the level of statistical significance is not that promising, still a positive relationship guarantees policy makers in the African countries that any effort to boost up trade levels in their economies will have desirable positive impacts on their economic growth rates.

These relationships are confirmed by Granger causality test to be uni-directional, running from economic growth to trade openness. However this is for the African countries as a whole because individual countries granger causality tests indicate mixed results. The policy implications of these results to policy makers is that comparatively permanent economic growth shocks induce larger long-run trade openness level responses, than the effect of permanent trade openness shocks on long-run economic growth. Therefore concentrating on enhancing policies that induce permanent economic growth may bring about the large positive long run trade openness changes for the African countries. In a way these conclusions supports the growth-driven export hypothesis discussed earlier in this paper.

However as some of the individual countries Granger causality Wald tests indicates, there are also cases where the causality runs from trade openness to economic growth. The implication of which is that economies should seek for adoption of outward oriented policies for them to achieve economic growth. However this has not been straight forward for many African countries. Deriving positive impacts from the integrating in the world economy, policy makers in African countries need to understand the effects of globalisation having in mind the set-up of their own countries. This is because globalisation has proved to oppose the notion of 'one size fits all'. African countries need to know how to manage the openness strategies they adopt so as to maximize the benefits of outward oriented strategies in the same time minimising the risks. This is in line with the argument by Rodriguez and Rodrik (2000) who argues that openness has potential benefits, but for these benefits to be realised the beneficiaries need to have quality and well established complementary policies and institutions.

Proper institutions and policies can protect these growing economies from external shocks and any possibility of domestic quarrels and political turmoil that could be produced. Thus, despite the economic development anxiousness that African countries might have, an emphasis of adopting openness through encouraging exports and direct foreign investments (alone) without strengthening their institutions and domestic policies could be hazardous. The end result in most cases has not been what was intended but rather ending up with economies that are doomed to disappointment and failure. Policy makers need to know that openness is a mixed blessing and it need to be nurtured well to have guaranteed positive results to the economy.

\section{References}

Adhikary, B.K., 2011. FDI, trade openness, capital formation, and economic growth in Bangladesh: A linkage analysis. International Journal of Business and Management, 6(1): 16-28. Available at: https://doi.org/10.5539/ijbm.v6n 1p 16 .

Aizenman, J. and I. Noy, 2003. Endogenous financial openness: Efficiency and political economy considerations (No. w10144). National Bureau of Economic Research.

Alfaro, L., A. Chanda, S. Kalemli-Ozcan and S. Sayek, 2004. FDI and economic growth: The role of local financial markets. Journal of International Economics, 64(1): 89-1 12. Available at: https://doi.org/10.1016/s0022-1996(03)00081-3.

Asiedu, E., 2002. On the determinants of foreign direct investment to developing countries: Is Africa different? World Development, 30(1): 107-1 19. Available at: https://doi.org/10.1016/s0305-750x(01)00100-0.

Asiedu, E., 2006. Foreign direct investment in Africa: The role of natural resources, market size, government policy, institutions and political instability. World Economy, 29(1): 63-77. Available at: https://doi.org/10.1111/j.1467-9701.2006.00758.x.

Awokuse, T.O., 2008. Trade openness and economic growth: Is growth export-led or import-led? Applied Economics, 40(2): 161-173. Available at: https://doi.org/10.1080/00036840600749490. 
Babatunde, A., 2011. Trade openness, infrastructure, FDI and growth in Sub-Saharan African countries. Journal of Management Policy and Practice, 12(7): 27-36

Bajwa, S. and M.W. Siddiqi, 2011. Trade openness and its effects on economic growth in selected South Asian countries: A panel data study. World Academy of Science, Engineering and Technology, 50(2): 1073-1078.

Borensztein, E., J. De Gregorio and J.W. Lee, 1998. How does foreign direct investment affect economic growth? Journal of International Economics, 45(1): 115-135. Available at: https://doi.org/10.1016/s0022-1996(97)00033-0.

Breitung, J., 2001. The local power of some unit root tests for panel data. In nonstationary panels, panel cointegration, and dynamic panels. Emerald Group Publishing Limited. pp: 161-177.

Breitung, J., 2002. Nonparametric tests for unit roots and cointegration. Journal of Econometrics, 108(2): 343-363. Available at: https://doi.org/10.1016/s0304-4076(01)00139-7.

Caner, M. and B.E. Hansen, 2004. Instrumental variable estimation of a threshold model. Econometric Theory, 20(5): 813-843.

Choi, I., 2001. Unit root tests for panel data. Journal of International Money and Finance, 20(2): 249-272.

Chow, P.C., 1987. Causality between export growth and industrial development: Empirial evidence from the NICs. Journal of Development Economics, 26(1): 55-63. Available at: https://doi.org/10.1016/0304-3878(87)90051-4.

Cinyabuguma, M.M. and L. Putterman, 2011. Sub-Saharan growth surprises: Being heterogeneous, Inland and close to the equator does not slow growth within Africa. Journal of African Economies, 20(2): 217-262. Available at: https://doi.org/10.1093/jae/ejq040.

David, H.L., 2007. A guide to measures of trade openness and policy. Mimeo: Indiana University South Bend.

Dickey, D.A. and W.A. Fuller, 1979. Distribution of the estimators for autoregressive time series with a unit root. Journal of the American Statistical Association, 74(366a): 427-431. Available at: https://doi.org/10.2307/2286348.

Din, M.U., 2004. Exports, imports, and economic growth in South Asia: Evidence using a multivariate time-series framework. The Pakistan Development Review, 43(2): 105-124. Available at: https://doi.org/10.30541/v43i2pp. 105-124.

Din., M.-U., G. Ejaz and S. Omer, 2003. Openness and economic growth in Pakistan. The Pakistan Development Review, 42(4): $795-807$. Available at: https://doi.org/10.30541/v42i4iipp.795-807.

Dollar, D. and A. Kraay, 2001. Trade growth and poverty. Finance and Development: 16-19.

Dowrick, S. and J. Golley, 2004. Trade openness and growth: Who benefits? Oxford Review of Economic Policy, 20(1): 38-56. Available at: https://doi.org/10.1093/oxrep/grhoo3.

Edwards, S., 1993. Openness, trade liberalization, and growth in developing countries. Journal of Economic Literature, 31 (3): $1358-1393$.

Ekanayake, E., R. Vogel and B. Veeramacheneni, 2003. Openness and economic growth: Empirical evidence on the relationship between output, inward FDI, and trade. Journal of Business Strategies, 20(1): 59-59.

Falvey, R., D. Greenaway and N. Foster, 2002. North-South trade, knowledge spillovers and growth (No. 15). European Economy Group.

Frankel, J.A. and D.H. Romer, 1999. Does trade cause growth? American Economic Review, 89(3): 379-399.

Grossman, G.M. and E. Helpman, 1991. Trade, knowledge spillovers, and growth. European Economic Review, 35(2-3): $517-526$.

Harrison, A., 1996. Openness and growth: A time-series, cross-country analysis for developing countries. Journal of Development Economics, 48(2): 419-447. Available at: https://doi.org/10.1016/0304-3878(95)00042-9.

Hassan, A.K. and M.R. Islam, 2005. Temporal causality and dynamics of financial development, trade openness, and economic growth in vector auto regression (VAR) for Bangladesh, 1974-2003: Implication for poverty reduction. Journal of Nepalese Business Studies, 2(1): 1-12. Available at: https://doi.org/10.3126/jnbs.v2i1.50.

Huchet-Bourdon, M., C. Le Mouël and M. Vijil, 2018. The relationship between trade openness and economic growth: Some new insights on the openness measurement issue. The World Economy, 41(1): 59-76. Available at: https://doi.org/10.1111/twec.12586.

Im, K.S., M.H. Pesaran and Y. Shin, 2003. Testing for unit roots in heterogeneous panels. Journal of Econometrics, 115(1): 53-74. Available at: https://doi.org/10.1016/s0304-4076(03)00092-7.

Kandiero, T. and M. Chitiga, 2006. Trade openness and foreign direct investment in Africa: Economics. South African Journal of Economic and Management Sciences, 9(3): 355-370.

Karras, G., 2003. Trade openness and economic growth can we estimate the precise effect? Applied Econometrics and International Development, 3(1): 7-24

Kee, H.L., C. Neagu and A. Nicita, 2013. Is protectionism on the rise? Assessing national trade policies during the crisis of 2008. Review of Economics and Statistics, 95(1): 342-346. Available at: https://doi.org/10.1162/rest_a_00241.

Kim, D.-H., 2011. Trade, growth and income. The Journal of International Trade \& Economic Development, 20(5): 677-709.

Klasra, M.A., 201 1. Foreign direct investment, trade openness and economic growth in Pakistan and Turkey: An investigation using bounds test. Quality \& Quantity, 45(1): 223-231. Available at: https://doi.org/10.1007/s11135-009-9272-5.

Kónya, L., 2006. Exports and growth: Granger causality analysis on OECD countries with a panel data approach. Economic Modelling, 23(6): 978-992. Available at: https://doi.org/10.1016/j.econmod.2006.04.008.

Koop, G., 2000. Analysis of economic data. Chichester: Wiley.

Krugman, P. and A.J. Venables, 1995. Globalization and the inequality of nations. The Quarterly Journal of Economics, 110(4): 857-880.

Levin, A., C.-F. Lin and C.-S.J. Chu, 2002. Unit root tests in panel data: Asymptotic and finite-sample properties. Journal of Econometrics, 108(1): 1-24. Available at: https://doi.org/10.1016/s0304-4076(01)00098-7.

Maddala, G.S. and S. Wu, 1999. A comparative study of unit root tests with panel data and a new simple test. Oxford Bulletin of Economics and Statistics, 61(S1): 631-652. Available at: https://doi.org/10.1111/1468-0084.61.s1.13.

Madsen, J.B., 2007. Technology spillover through trade and TFP convergence: 135 years of evidence for the OECD countries. Journal of International Economics, 72(2): 464-480. Available at: https://doi.org/10.1016/j.jinteco.2006.12.001.

Manole, V. and M. Spatareanu, 2010. Trade openness and income-a re-examination. Economics Letters, 106(1): 1-3. Available at: https://doi.org/10.1016/j.econlet.2009.06.021.

Marelli, E. and M. Signorelli, 2011. China and India: Openness, trade and effects on economic growth. The European Journal of Comparative Economics, 8(1): 129-155

Menyah, K., S. Nazlioglu and Y. Wolde-Rufael, 2014. Financial development, trade openness and economic growth in African countries: New insights from a panel causality approach. Economic Modelling, 37(C): 386-394. Available at: https://doi.org/10.1016/j.econmod.2013.11.044.

Mercan, M., I. Gocer, S. Bulut and M. Dam, 2013. The effect of openness on economic growth for BRIC-T countries: Panel data analysis. Eurasian Journal of business and Economics, 6(1 1): 1-14.

Nannicini, T. and A. Billmeier, 2011. Economies in transition: How important is trade openness for growth? Oxford Bulletin of Economics and Statistics, 73(3): 287-314. Available at: https://doi.org/10.1111/j.1468-0084.2010.00626.x.

Onafowora, O.A. and O. Owoye, 1998. Can trade liberalization stimulate economic growth in Africa? World Development, 26(3): 497-506. Available at: https://doi.org/10.1016/s0305-750x(97)10058-4

Rodriguez, F. and D. Rodrik, 2000. Trade policy and economic growth: a skeptic's guide to the cross-national evidence. NBER Macroeconomics Annual, 15: 261-325.

Rodriguez, F. and D. Rodrik, 2001. Trade policy and economic growth: A skeptic's guide to the cross-national evidence. NBER Macroeconomics Annual 2000, MIT Press, 15: 261-338.

Rose, A., 2002. Do WTO members have more liberal trade policy? (No. 3659). CEPR Discussion Papers.

Salvatore, D., 1998. Europe's structural and competitiveness problems and the Euro. World Economy, 21(2): 189-205. Available at: https://doi.org/10.1111/1467-9701.00126.

Sarkar, P., 2008. Trade openness and growth: Is there any link? Journal of Economic Issues, 42(3): 763-785. Available at: https://doi.org/10.1080/00213624.2008.11507178.

Seetanah, B., 2009. The economic importance of education: Evidence from Africa using dynamic panel data analysis. Journal of Applied Economics, 12(1): 137-157. Available at: https://doi.org/10.1016/s15 14-0326(09)60009-x.

Seetanah, B., 2011. Assessing the dynamic economic impact of tourism for Island economies. Annals of Tourism Research, 38(1): 291-308. Available at: https://doi.org/10.1016/j.annals.2010.08.009. 
Seetanah, B., U. Subadar, R.V. Sannassee, M. Lamport and V. Ajageer, 2012. Stock market development and economic growth: Evidence from least developed countries. Berlin: College of Technology and Economics.

Tsangarides, C.G., 2001. On cross-country growth and convergence: Evidence from African and OECD countries. Journal of African Economies, 10(4): 355-389. Available at: https://doi.org/10.1093/jae/10.4.355.

Yanikkaya, H., 2003. Trade openness and economic growth: A cross-country empirical investigation. Journal of Development Economics, 72(1): 57-89. Available at: https://doi.org/10.1016/s0304-3878(03)00068-3. 